Jurnal Cendekia Akuntansi

Kediri, Desember 2021

\title{
ANALISIS PSAK 24 ATAS IMBALAN KERJA DALAM LAPORAN KEUANGAN PADA PG PESANTREN BARU KEDIRI
}

\author{
Lembayung Nurkumalasari \\ Eni Srihastuti \\ Universitas Islam Kadiri \\ E-mail: Lembayungkumalasari66@gmail.com, \\ enisrihastuti@uniska-kediri.ac.id
}

\begin{abstract}
Abstraksi
Imbalan kerja adalah balas jasa yang diberikan oleh perusahaan kepada karyawannya. Dalam memberikan imbalan kerja kepada karyawannya perusahaan harus mematuhi standar akuntansi keuangan yang berlaku di Indonesia yaitu PSAK 24 yang membahas mengenai pengukuran, pengakuan dan pengungkapan imbalan kerja. Dalam penelitian ini memfokuskan pada penelitian imbalan jangka pendek dan imbalan jangka panjang lain. Tujuan dilakukan penelitian ini adalah untuk mengetahui bagaimana perlakuan imbalan jangka pendek dan imbalan jangka panjang lain yang diterapkan oleh PG Pesantren Baru Kediri. Penelitian ini menggunakan metode deskriptif kuantitatif, dengan pengumpulan data melalui observasi dan wawancara. Hasil penelitian ini menunjukkan bahwa PG Pesantren Baru dalam memberikan imbalan jangka pendek dan imbalan jangka panjang lain telah sesuai dengan PSAK 24. Namun dalam perhitungan bonus perlu diperjelas perhitungannya.
\end{abstract}

Kata Kunci : Imbalan Jangka Pendek, Imbalan Jangka Panjang Lain, PSAK 24.

\begin{abstract}
Employee benefits are remuneration provided by the company to its employees. In providing employee benefits, the company must comply with the applicable financial accounting standards in Indonesia, namely PSAK 24 which discusses the measurement, recognition and disclosure of employee benefits. This research focuses on research on short-term rewards and other long-term rewards. The purpose of this study was to find out how the treatment of short-term rewards and other long-term rewards applied by PG Pesantren Baru Kediri. This study uses a quantitative descriptive method, with data collection through observation and interviews. The results of this study indicate that PG Pesantren Baru in providing short-term rewards and other long-term benefits has complied with PSAK 24. However, the calculation of bonuses needs to be clarified.
\end{abstract}

Keywords: Short-Term Benefits, Other Long-Term Benefits, PSAK 24. 


\section{PENDAHULUAN}

Dalam dunia bisnis, tenaga kerja merupakan penggerak dalam proses produksi dan operasional suatu perusahaan. Maka dari itu aktivitas tenaga kerja dalam suatu perusahaan baik itu hal-hal yang menyangkut pelatihan tenaga kerja maupun hak tenaga kerja yang diberikan oleh perusahaan berupa imbalan kerja harus dilaporkan dalam laporan keuangan perusahaan. Dalam membuat laporan keuangan suatu perusahaan tidak boleh sembarangan, harus mengikuti standar pelaporan keuangan yang berlaku disuatu negara.

Di Indonesia terdapat lembaga khusus yang mengatur mengenai standar laporan keuangan sebuah perusahaan baik laba dan nirlaba yang memiliki akuntabilitas publik yaitu Ikatan Akuntan Indonesia (IAI). Setiap tahunnya IAI selalu mengadakan rapat tahunan guna membahas mengenai SAK (Standar Akuntansi Keuangan). PSAK 24 merupakan hasil adopsi dari IFRS yaitu IAS 19 Employe Benefit sehingga setiap tahunnya selalu ada penyesuaian. PSAK 24 mengalami penyesuain terakhir pada tahun 2018 dan mulai efektif pada tanggal 1 Januari 2019 dengan diperkenankannya opsi penerapam dini.

Pabrik Gula Pesantren baru merupakan unit usaha dari PT Perkebunan Perkebunana Nusantara X (Persero) yaitu suatu perusahaan manufaktur yang mengolah tebu menjadi gula pasir putih. Perusahaan memiliki kapasitas giling 6.000 TCD. Jumlah karyawan PG Pesantren Baru Kediri dalam masa produksi menyerap sebanyak 1032 orang. Diluar masa giling perusahaan menyerap tenaga kerja sebanyak kurang lebih 449 orang. Sehingga pengukuran, pengakuan dan pengungkapan imbalan kerja yang sesuai dengan standar akuntansi yang digunakan oleh perusahaan perlu diketahui, sebab pemberian imbalan kerja yang sesuai dengan standar yang berlaku akan mempengaruhi kinerja karyawan dan dapat mengurangi dampak adanya hubungan industrial dengan karyawan. Pemberian imbalan kerja, cuti dan tunjangan-tunjangan yang diberikan pihak perusahaan tersebut, belum sepenuhnya mengikuti standar akuntansi mengenai imbalan kerja yang telah ditetapkan karena sebelumnya belum ada yang meneliti.

Berdasarkan permasalahan diatas peneliti terdorong untuk mengetahui bagaimana perlakuan PSAK 24 di perusahaan tersebut, maka disusunlah skripsi ini dengan judul "Analisis PSAK 24 Atas Imbalan Kerja dalam Laporan Keuangan Pabrik Gula Pesantren Baru Kediri." Tujuan yang diharapkan dari adanya penelitian ini adalah untuk mengetahui perlakuan imbalan kerja jangka pendek dan jangka panjang lain karyawan tetap pada perusahaan dan kesesuaian pengukuran, pengakuan dan pengungkapan dengan PSAK 24 atas imbalan kerja.

\section{TINJAUAN PUSTAKA \\ Pengertian Imbalan Kerja}

Menurut PSAK 24 revisi 2018, imbalan kerja adalah seluruh bentuk imbalan yang diberikan perusahaan sebagai pertukaran atas jasa yang diberikan oleh pekerja atau untuk terminasi kontrak kerja. 


\section{Tujuan Imbalan Kerja}

Menurut Undang-Undang Nomer 13 Tahun 2003 pasal 88 tujuan pemberian imbalan kerja adalah untuk mewujudkan penghasilan yang memenuhi penghidupan yang layak bagi kemanusiaan sebagaimana di maksudkan dalam ayat (1), pemerintah menetapkan kebijakan pengupahan yang melindungi pekerja/buruh.

\section{Macam-Macam Imbalan Kerja}

Dalam PSAK 24, revisi 2018 imbalan kerja dibagi menjadi 4 macam yaitu:

1. Imbalan Jangka Pendek

Imbalan kerja (selain dari pesangon) yang diharapkan akan selesai seluruhnya sebelum 12 bulan setelah akhir periode pelaporan tahunan saat pekerja memberikan jasanya. Terdiri dari:

a. Upah, gaji dan iuran jaminan sosial

b. Cuti tahunan berbayar dan cuti sakit berbayar

c. Bagi laba dan bonus

d. Imbalan nonmoneter, meliputi : pelayanan kesehatan, rumah, mobil dan barang atau jasa yang diberikan cuma-cuma atau melalui subsidi) untuk pekerja yang ada.

\section{Imbalan Jangka Panjang Lain}

Seluruh imbalan kerja yang tidak diharapkan akan selesai seluruhnya sebelum dua belas bulan setelah akhir periode pelaporan tahunan saat pekerja memberikan jasanya. Terdiri dari:
a. Cuti berbayar jangka panjang seperti cuti besar atau cuti sabbatical
b. Penghargaan masa kerja
c. Imbalan cacat permanen
d. Bagi laba dan bonus
e. Remunerasi tangguhan

3. Imbalan Pascakerja

Imbalan kerja yang terutang setelah pekerja meyelesaikan kontrak kerja. Terdiri dari:

a. Imbalan punakarya (contohnya pensiun dan pembayaran lump sum pada saat punakarya)

b. Imbalan pascakerja lain seperti asuransi jiwa pascakerja dan fasilitas pelayanan kesehatan pascakerja

4. Pesangon

Imbalan yang diberikan dalam pertukaran atas terminasi perjanjian kerja dengan pekerja. Terdiri dari :

a. Keputusan entitas untuk memberhentikan pekerja sebelum usia punakarya normal.

b. Keputusan pekerja menerima tawaran imbalan sebagai pertukaran atas terminasi perjanjian kerja. 


\section{Pengakuan dan Pengukuran Imbalan Kerja}

Dalam PSAK 24, revisi 2018 pengakuan dan pengukuran imbalan kerja, sebagai berikut:

\section{Imbalan Jangka Pendek}

Untuk seluruh imbalan jangka pendek, ketika pekerja telah memberikan jasanya kepada entitas dalam suatu periode akuntansi, entitas mengakui jumlah tidak terdiskonto dari imbalan kerja jangka pendek yang diharapkan akan dibayar sebagai imbalan atas jasa tersebut :

a. Sebagai liabilitas ( beban akrual), setelah dikurangi jumlah yang sudah dibayar.

b. Sebagai beban

\section{Imbalan Jangka Panjang Lain}

Pengukuran imbalan kerja jangka panjang lain tidak bergantung pada tingkat ketidakpastian seperti halnya pengukuran pada imbalan pascakerja. Maka dari itu, PSAK 24 mensyaratkan metode akuntansi disederhanakan untuk imbalan jangka panjang lain. Berbeda dengan akuntansi yang disyaratkan pada imbalan pascakerja.

3. Imbalan Jangka Pascakerja

a. Program Iuran Pasti

Apabila pekerja telah memberikan jasa kepada perusahaan pada periode akuntansi, perusahaan mengakui iuran terutang kepada program iuran pasti atas jasa pekerja. Sebagai liabilitas (beban akrual) setelah dikurangi dengan iuran yang telah dibayar. Apabila iuran yang sudah dibayar melebihi iuran terutang untuk jasa sebelum akhir periode pelaporan, maka entitas mengakui kelebihan tersebut sebagai aset (beban di bayar dimuka) sepanjang kelebihan tersebut mengurangi pembayaran iuran masa depan atau pembayaran kembali dalam bentuk kas dan dapat diakui sebagai beban.

b. Program Imbalan Pasti

Untuk proses akuntansi program imbalan kerja yang dilakukan perusahaan adalah sebagai berikut:

1. Menentukan defisit atau surplus menggunakan teknik aktuarial, metode Project Unit Credit.

2. Menentukan jumlah liabilitas (aset) imbalan pasti neto sebagai jumlah defisit atau surplus.

3. Menentukan jumlah yang diakui dalam laba rugi.

4. Menentukan pengukuran kembali atas liabilitas (aset) imbalan pasti neto, yang akan diakui sebagai penghasilan komprehensif. (Lisa,2015)

4. Pesangon

Perusahaan mengukur pesangon pada saat pengakuan awal, dan mengukur dan mengakui perubahan selanjutnya, sesuai dengan sifat imbalan kerja, dengan ketentuan bahwa jika pesangon merupakan sebuah peningkatan pada imbalan pascakerja, maka entitas menerapkan persyaratan imbalan pascakerja, sebaliknya: 
a. Apabila pesangon diharapkan akan diselesaikan kurang dari 12 sebelum pelaporan akhir maka masuk kedalam persyaratan imbalan jangka pendek.

b. Apabila pesangon tidak diharpkan akan diselesaikan 12 bulan sebelum pelaporan akhir maka masuk kedalam persyaratan imbalan jangka panjang lain. .

Perusahaan mengakui liabilitas dan beban pesangon pada tanggal yang lebih awal diantara:

a. Ketika perusahaan tidak dapat menarik tawaran atas imbalan.

b. Ketika perusahaan mengakui biaya untuk restrukturisasi yang berada dalam ruang lingkup PSAK 57: Provisi, Liabilitas Kontinjensi dan Aset Kontinjensi dan melibatkan pembayaran pesangon.

\section{Pengungakapan Imbalan Kerja}

Dalam PSAK 24, revisi 2018 pengungkapan imbalan kerja sebagai berikut:

1. Imbalan Jangka Pendek, Imbalan Jangka Panjang Lain dan Pesangon.

Pernyataan ini tidak mensyaratkan pengungkapan spesifik mengenai imbalan jangka pendek, imbalan jangka panjang lain dan pesangon. SAK mungkin mensyaratkan pengungkapan tersebut. Sebagai contoh PSAK 7: Pengungkapan Pihak-Pihak Berelasi mensyaratkan pengungkapan mengenai imbalan kerja untuk personil manajemen kunci. PSAK 1: Penyajian Laporan Keuangan mensyaratkan pengungkapan beban imbalan kerja.

2. Imbalan Jangka Pascakerja

a. Program Imbalan Pasti

Perusahaan mengungkapkan informasi yang memberikan kerjalasan mengenai karakteristik program imbalan pasti dan resikonya. Serta memberikan penjelasan terhadap jumlah yang timbul dari program imbalan pasti dalam laporan keuangan. Menjelaskan bagaimana program imbalan pasti berdampak terhadap jumlah, waktu dan ketidakpastian arus kas entitas di masa depan.

b. Program Iuran Pasti

Entitas mengungkapkan jumlah yang diakui sebagai beban untuk program iuran pasti. Sebagaimana disyaratkan oleh PSAK 7: Pengungkapan PihakPihak Berelasi, entitas mengungkapkan informasi tentang iuran kepada program iuran pasti untuk personil manajemen kunci.

\section{METODE PENELITIAN}

Jenis penelitian ini merupakan jenis penelitian deskriptif kuantitatif. Data yag peneliti peroleh berupa data kuantitatif dan data kualitatif. Sumber data yang peneliti peroleh yaitu berupa sumber data primer yang didapat langsung dari sumbernya. Serta teknik pengumpulan data melalui dua cara yaitu wawancara dan dokumentasi. 


\section{HASIL PENELITIAN}

Jumlah karyawan tetap di PG Pesantren Baru pada tahun 2020 sebanyak 241 orang. Dalam memberikan gaji kepada karyawan tetap berdasarkan grade yang telah ditentukan oleh perusahaan. Berikut merupakan jumlah karyawan tetap berdasarkan gradenya:

Tabel 1 Jumlah Karyawan

\begin{tabular}{|c|c|}
\hline Grade & $\begin{array}{c}\text { Jumlah Karyawan } \\
\text { Tetap }\end{array}$ \\
\hline $5-8$ & 83 orang \\
\hline $9-12$ & 128 orang \\
\hline $13-16$ & 20 orang \\
\hline Total & 241 orang \\
\hline
\end{tabular}

Sumber: PG Pesanren Baru, 2021

Perusahaan beroperasi pada dua masa yaitu dalam masa giling dan diluar masa giling. Untuk perhitungan lembur perjam yaitu $1 / 173$ x gaji. Perusahaan bekerjasama dengan BPJS Ketenaga kerjaan dalam memberikan jaminan sosial kepada karyawan tetapnya berupa JKK dan JK. Karyawan yang menjabat sebagai pejabat punjak dan pejabat manajer di unit usaha/ kepala urusan di kantor pusat diberikan tunjangan sebesar $80 \%$ x faktor. Untuk karyawan tetap akan diberikan tunjangan managerial sesuai grade, karyawan yang berhak mendapat tunjangan managerial yaitu karyawan tetap yang memiliki grade 1-12.

Perusahaan memberikan cuti kepada karyawan berupa cuti melahiran selama 3 bulan dan cuti tetap mendapatkan gaji. Serta diberikan cuti tahunan sebesar 12 hari dengan diberikan tunjangan cuti $50 \%$ x gaji. Karyawan tetap juga mendapatkan imbalan non moneter yaitu berupa pakaian dinas sebanyak 2 baju setia tahun dan gula icip-icip yang besarnya sesuai dengan grade karyawan. Untuk seluruh karyawan tetap akan diberikan santunan sosial berupa bantuan sewa rumah, listrik, air dan bahan bakar yang besarnya sesuai dengan grade karyawan.

Selain itu kayawan juga mendapat tunjangan hari raya keagamaan. Bagi karyawan tetap yang telah bekerja secara terus menerus selama 6 tahun berhak atas cuti panjang 1 bulan dan diberikan tunjangan cuti panjang sebesar 1 bulan gaji pokok. Kepada karyawan yang telah bekerja secara terus menerus tanpa terputus selama 20 tahun, 30 tahun dan 35 tahun dan menunjukkan kesetiaannya pada negara dan perusahaan akan diberikan penghargaan masa pengabdian, perhitungannya sebagai berikut:

Tabel 2 Penghargaan Karyawan

\begin{tabular}{|c|c|}
\hline Masa Pengabdian & Perhitungan \\
\hline 20 Tahun & Uang tunai sebesar 3 bulan Gaji \\
\hline 25 Tahun & $\begin{array}{l}\text { Uang tunai sebesar } 3 \text { bulan Gaji }+ \\
\text { medali emas } 22 \mathrm{k} \text { sebesar } 10 \text { gram }\end{array}$ \\
\hline 30 Tahun & $\begin{array}{l}\text { Uang tunai sebesar } 3 \text { bulan Gaji }+ \\
\text { medali emas } 22 \mathrm{k} \text { sebesar } 5 \text { gram }\end{array}$ \\
\hline 35 Tahun & $\begin{array}{l}\text { Uang tunai sebesar } 3 \text { bulan Gaji }+ \\
\text { medali emas } 22 \mathrm{k} \text { sebesar } 5 \text { gram }\end{array}$ \\
\hline
\end{tabular}

Sumber: PG Pesantren Baru Kediri, 2021 
Tabel 3 Bantuan Untuk Karyawan yang Sakit

\begin{tabular}{|l|l|}
\hline \multicolumn{1}{|c|}{ Bulan } & Perhitungan \\
\hline 1 sd 4 & $\begin{array}{l}\text { 100\% Gaji pokok + Santunan khusus } \\
\text { +(Tunjangan manajerial + Tunjangan } \\
\text { jabatan) + 100\% Sansos }\end{array}$ \\
\hline 5 sd 8 & $\begin{array}{l}75 \% \text { Gaji pokok + Santunan khusus + } \\
\text { (Tunjangan manajerial + Tunjangan } \\
\text { jabatan })+100 \% \text { Sansos }\end{array}$ \\
\hline 9 sd 12 & $\begin{array}{l}50 \% \text { Gaji pokok + Santunan khusus + } \\
\text { (Tunjangan manajerial + Tunjangan } \\
\text { jabatan) }+100 \% \text { Sansos }\end{array}$ \\
\hline $\begin{array}{l}\text { Bulan } \\
\text { berikutnya }\end{array}$ & $\begin{array}{l}\text { (Tunjangan mani pokok + Santunan khusus + } \\
\text { jabatan) }+100 \% \text { Sansos }+ \text { Tunjangan }\end{array}$ \\
\hline
\end{tabular}

Sumber: PG Pesantren Baru Kediri, 2021

Tabel 4 Bantuan Bagi karyawan yang ditahan alat negara

\begin{tabular}{|c|c|}
\hline $\begin{array}{l}\text { Jumlah } \\
\text { Tanggungan }\end{array}$ & Perhitungan \\
\hline $\begin{array}{l}1 \text { orang } \\
\text { tanggungan }\end{array}$ & $\begin{array}{l}25 \% \text { Gaji pokok + Santunan khusus }+ \\
\text { (Tunjangan manajerial }+ \text { Tunjangan } \\
\text { jabatan) }+ \text { Sansos }\end{array}$ \\
\hline $\begin{array}{l}2 \text { orang } \\
\text { tanggungan }\end{array}$ & $\begin{array}{l}35 \% \text { Gaji pokok + Santunan khusus }+ \\
\text { (Tunjangan manajerial }+ \text { Tunjangan } \\
\text { jabatan) }+ \text { Sansos }\end{array}$ \\
\hline $\begin{array}{l}3 \text { orang } \\
\text { tanggungan }\end{array}$ & $\begin{array}{l}45 \% \text { Gaji pokok + Santunan khusus }+ \\
\text { (Tunjangan manajerial }+ \text { Tunjangan } \\
\text { jabatan) }+ \text { Sansos }\end{array}$ \\
\hline $\begin{array}{l}4 \text { orang } \\
\text { tanggungan }\end{array}$ & $\begin{array}{l}50 \% \text { Gaji pokok + Santunan khusus }+ \\
\text { (Tunjangan manajerial }+ \text { Tunjangan } \\
\text { jabatan) }+ \text { Sansos }\end{array}$ \\
\hline
\end{tabular}

Sumber: PG Pesantren Baru Kediri, 2021

\section{Klasifikasi Imbalan Kerja}

Berdasarkan perolehan data mengenai imbalan jangka pendek dan imbalan jangka panjang lain di perusahaan, peneliti kemudian mengklasifikasikan imbalan-imbalan tersebut ke dalam imbalan jangka pendek dan imbalan jangka panjang lain sesuai PSAK 24 sebagai berikut:

1. Imbalan Jangka Pendek

Gaji, upah lembur ,tunjangan manajerial, tunjangan jabatan, santunan sosial, iuran jaminan sosial, cuti berbayar, cuti Melahirkan, cuti tahunan, imbalan non moneter ( pakaian dinas, gula icip-icip), THR, bonus.

2. Imbalan Jangka Panjang Lain

Cuti panjang, karyawan sakit berkepanjangan, karyawan yang ditahan alat negara, penghargaan masa pengabdian. 


\section{Pencatatan Imbalan Kerja}

Dalam mencatat imbalan kerja baik jangka panjang dan jangka pendek perusahaan mencatat saat pengakuan dan saat realisasi. Contohnya dalam menjurnal gaji:

Saat pengakuan :

$\begin{array}{ll}\text { Gaji } & \text { Rp 17.507.213.887 } \\ \text { Hutang Karyawan } & \text { Rp 17.507.213.887 }\end{array}$

Saat realisasi:

Hutang Karyawan Rp 17.507.213.887

Kas $\quad$ Rp 17.507.213.887

\section{Pengukuran Imbalan Kerja}

1. Imbalan Jangka Pendek

Dalam mengukur imbalan jangka pendek meliputi gaji pokok, upah lembur, tunjangan manajerial, tunjangan jabatan, THR, cuti melahirkan, cuti haid, cuti tahunan, imbalan non moneter untuk pengukurannya PG Pesantren Baru telah mengatur pengukuran imbalan kerja jangka pendek terhadap karyawan tetapnya dalam perjanjian kerja bersama dan dipaparkan secara jelas. Dalam pengukuran bonus perusahaan tidak memberikan perhitungan yang spesifik terhadap pemberian bonus.

2. Imbalan Jangka Panjang Lain

Pengukuran imbalan kerja jangaka panjang lain di perusahaan, untuk rumus perhitungannya telah diatur secara jelas dalam perjanjanjian kerja bersama antara pihak perusahaan dan pihak karyawan

\section{Pengakuan Imbalan Kerja}

1. Imbalan Jangka Pendek

Untuk pengakuan imbalan jangka pendek PG Pesantren Baru meliputi gaji pokok,uang lembur, tunjangan jabatan, tunjangan manajerial, cuti tahunan, iuran jaminan sosial, imbalan non moneter meliputi pakaian dinas, gula icipicip mengakuinya saat imbalan tersebut terutang kepada karyawan dan diakui sebagai beban usaha dalam laporan laba rugi. Pada tahun 2020 tidak ada karyawan yang mengambil cuti melahirkan dan tidak diberikannya bonus kepada karyawan, maka perusahaan tidak mengakui imbalan tersebut.

2. Imbalan Jangka Panjang Lain

Untuk pengakuan imbalan jangka panjang lain PG Pesantren Baru yang melipti cuti jangka panjang, sakit berkepanjangan, ditahan alat negara, penghargaan masa kerja diakui saat terjadinya peristiwa tersebut. Untuk sakit berkepanjangan dan ditahan alat negara untuk tahun 2020 tidak ada karyawan yang mengalami hal tersebut sehingga perusahaan tidak mengakui dalam laporan keuangan. Untuk penghargaan masa pengbdian, dan cuti panjang perusahaan mengakui dalam laporan keuangan saat terjadi peristiwa tersebut dan mengakuinya sebagai beban usaha dalam laporan laba rugi. Pada tahun 2020 tidak ada karyawan yang sakit berkepanjangan dan ditahan alat negara sehingga perusahaan tidak mengakui imbalan tersebut dalam laporan keuangan. 


\section{Pengungkapan Imbalan Kerja}

1. Imbalan Jangka Pendek

Untuk penguangkapan imbalan jangka pendeknya perusahaan mengungkapan imbalan jangka pendek yaitu gaji, tunjangan manajerial, tunjangan jabatan, THR, cuti tahunan, santunan sosial, iuran jaminan sosial, upah lembur, imbalan nonmoneter secara keseluruhan dalam laporan keuangan.

2. Imbalan Jangka Panjang Lain

Untuk penguangkapan imbalan jangka panjang lainnya perusahaan mengungkapan imbalan jangka panjang lain secara keseluruhan dalam laporan keuangan sesuai dengan peristiwa yaang terjadi dalam periode akuntansi. Imbalan jangka panjang lain yang diungkapan dalam laporan keuangan pada tahun 2020 yaitu cuti jangka panjang dan pernghargaan masa pengabdian.

\section{SIMPULAN DAN SARAN}

Berdasarkan analisis peneliti terkait dengan pengukuran, pengakuan dan pengungkapan imbalan jangka pendek dan imbalan jangka panjang lain di PG Pesantren Baru Kediri dan kesesuainnya dengan PSAK 24. Berikut kesimpulan yang dapat diambil :

1. Untuk pengukuran sebagian besar imbalan kerja jangka pendek dan imbalan jangka panjang lain PG Pesantren telah mengukur imbalan sesuai dengan PSAK 24. Namun dalam pengukuran bonus perlu diperjelas perhitungannya.

2. Untuk pengakuan imbalan jangka pendek dan imbalan jangka panjang lain PG Pesantren Baru telah mengakui imbalan sesui dengan PSAK 24.

3. Untuk pengungkapan imbalan jangka pendek dan imbalan jangka panjang lain, PG Pesantren Baru Kediri telah mengungkapan seluruh beban imbalan kerja dalam laporan keuangan dan telah sesuai dengan ketentuan yang disyaratkan dalam PSAK 24.

Peneliti memberikan saran kepada perusahaan untuk selalu mengikuti perkembangan terbaru mengenai peraturan perundang-undangan yang berlaku di Indonesia khususnya mengenai pemberian imbalan kerja, terutama dengan UU Cipta Kerja. Serta selalu mengikuti perkembangan terbaru mengenai standar akuntansi keuangan (SAK) khususnya PSAK 24. Perusahaan perlu memperjelas perhitungan terkait pemberian bonus kepada karyawan

\section{DAFTAR PUSATAKA}

Ikatan Akuntan Indonesia. (2018) . Standar Akuntansi Keuangan. Jakarta: Dewan Standar Akuntansi Keuangan

Kieso, Weygandt and Walfield. (2014). Intermediate Accounting IFRS edition Volume 2. Hoboken: John Wiley

Lisa, Longdong Inggrit. (2015).“Analisa Pengakuan, Pengukuran dan Pengungkapan Imbalan Kerja Berdasarkan PSAK No 24 Tentang Imbalan Kerja pada PT Hasjrat Abadi Manado." Universitas Sam Ratulangi. (Online). (Diakses 24 Januari 2021). 
Marisi, P Purba. (2012).Akuntansi dan Pelaporan Keuangan Imbalan Kerja Panduan Penerapan PSAK 24 (Revisi 2010) Tentang Imbalan Kerja. Yogyakarta:Graha Ilmu

Monalisa, Treesje Runtu, Robert Lambey.(2018). "Analisis Penerapan Imbalan Pasca Kerja Pada Karyawan PT Moy Veronika.” Universitas Sam Ratulangi. (Online).(Diakses 25 Januari 2021).

Nefry Pajowa A, Sifrid S Pangemanan, Sonny Pangerapan.(2019).“Analisis Penerapan PSAK 24 Atas Imbalan Kerja Pada PT Angkasa Pura I (Persero) Bandara Sam Ratulangi Manado". Universitas Sam Sam Ratulangi.(Online). (Diakses 24 Januari 2021)

Syaiful ,Bahri. (2019). Pengantar Akuntansi berdasarkan SAK ETAP dan IFRS. Yogyakarta: CV Andi Offset

Tantya, Rizka.(2018).“Analisis Penerapan PSAK 24 Tentang Imbalan Kerja Pada Otoritas Jasa Keuangan.” Indonesia Banking School Jakarta. Skripsi. (Online). (Diakses 26 Januari 2021).

Undang Undang Republik Indonesia Nomor 13 Tahun 2003 Tentang Ketenagakerjaan

Watung, Mercy Natalia, Grace B Nangoi, Rudy J Pusung. (2016).”Analisis Penerapan PSAK 24 Mengenai Imbalan Kerja pada PT Bank Maybank Indonesia TBK KCP Kotamobagu." Universitas (Online).(Diakses 24 Januari 2021). 